\title{
A technique for the processing of blood samples for subsequent assay of ATP, and an investigation of the method of standardization of the firefly-luciferase ATP assay*
}

Quantitative measurement of adenosine triphosphate (ATP) in erythrocytes is of increasing interest in genetic studies of human population groups ${ }^{1}$. The concentration of ATP in erythrocytes appears to be under at least partial genetic control ${ }^{\mathbf{1 , 2}}$, and recently has been shown to be of potential significance in selective processes related to malaria ${ }^{3}$. In addition, measurcment of crythrocytic ATP is of importance in certain clinical situations ${ }^{4}$, particularly in connection with blood banking ${ }^{5-11}$.

At present, accurate evaluation of the physiological level of ATP of erythrocytes can only be made on reasonably fresh blood samples, and then only if the samples are stored in acid-citrate-dextrose (ACD) solution and kept carefully refrigerated at all times ${ }^{12}$. Even with such precautions, appreciable changes in levels of ATP may occur after only a few days of storage. A method is herein described in which blood can be collected and processed in the field, the samples stored in the frozen state for up to six weeks, and accurate determination of ATP subsequently made in the investigator's base laboratory. In addition, we have reinvestigated the method of standardization employed in the firefly-luciferase luminescence assay for ATP of erythrocytes ${ }^{13}$.

METHODS

Adenosine triphosphate was assayed by a modification of the enzymatic** method of Kornberg ${ }^{14}$ as previously described ${ }^{4}$, and by the firefly-luciferase lumi-

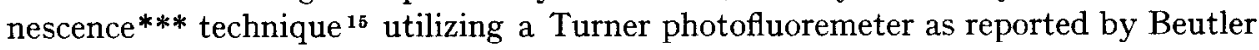
and Baluda ${ }^{13}$.

Sample storage technique for ATP assay

Venous blood is taken into either heparin or ACD (0.I5 $\mathrm{ml} \mathrm{NIH} \mathrm{formula-A}$ ACD per I.o $\mathrm{ml}$ blood) as anticoagulants. A hemoglobin determination is performed on an aliquot of the sample. Then 5 to ro $\mathrm{ml}$ of blood (accurately measured) are pipetted into a large test tube (approximately $50 \mathrm{ml}$ size), and two volumes of $6.7 \%$ trichloracetic acid (TCA) added. The top of the tube is covered with laboratory film and the tube shaken vigorously for about $30 \mathrm{sec}$. This mixture is then frozen and stored in the frozen state $\left(-20^{\circ}\right.$ is sufficient) until ready for assay. The addition of TCA and freezing can be delayed for up to $24 \mathrm{~h}$ if ACD is added to the blood promptly and if the blood is kept at $4^{\circ}$. After freezing the sample can be stored frozen for at least six weeks.

* This investigation was supported by research grant AM-o938 I and by Career Development $\Lambda$ ward I K3-AM-7959 (Dr. Brewer), both from the National Institute of Arthritis and Metabolic Diseases U.S. Public Health Service.

** Referred to as the "enzymatic" method in this paper.

*** Referred to as the "luminescence" method in this paper.

Clin. Chim. Acta, I4 (1966) 836-839 
At the time of assay, the mixtures are rapidly thawed under warm running water or in a warm water bath (not warmer than $37^{\circ}$ ). After thawing is complete (usually within $15-20 \mathrm{~min}$ ) the mixtures are centrifuged at a minimum of $14000 \times \mathrm{g}$ for $40 \mathrm{~min}$ at $4^{\circ}$. The clear supernatant is quantitatively removed, measured, and assayed for ATP as previously described ${ }^{4}$. By appropriate calculations based on the volume of blood extracted, the hemoglobin concentration of the blood prior to extraction, the volume of extract, and the assay results, the content of ATP per gram of hemoglobin is determined.

\section{RESULTS}

\section{Evaluation of the sample storage technique for ATP assay}

Venous blood was collected from 20 volunteers and divided into two aliquots. Assays of ATP by the enzymatic method were carried out promptly on one aliquot, while the other was processed and frozen for 6 weeks according to the sample storage technique described in the METHODs section. After 6 weeks the stored samples were once again assayed by the "enzymatic" technique. Results are shown in Table I. The assays prior to storage and those after storage were closely correlated (correlation coefficient of +0.828 ), and the mean values were almost identical.

TABLE I

\begin{tabular}{lll}
\hline Sample No. & $\begin{array}{l}\text { ATP assay prior } \\
\text { to storage }\end{array}$ & $\begin{array}{l}\text { ATP assay after } \\
6 \text { tweeks storage }\end{array}$ \\
\hline I & $2.07^{*}$ & $3.03^{*}$ \\
2 & 3.79 & 3.96 \\
3 & 3.90 & 4.11 \\
4 & 3.07 & 3.42 \\
5 & 4.16 & 3.92 \\
6 & 2.88 & 3.24 \\
7 & 3.45 & 3.53 \\
8 & 3.21 & 3.86 \\
9 & 4.35 & 4.01 \\
I0 & 4.50 & 4.57 \\
II & 4.41 & 3.96 \\
I 2 & 3.71 & 3.36 \\
I3 & 3.68 & 3.36 \\
I4 & 3.09 & 3.26 \\
I5 & 2.49 & 2.72 \\
x6 & 3.33 & 2.92 \\
I7 & 2.84 & 2.61 \\
I8 & 3.38 & 3.49 \\
I9 & 3.54 & 3.38 \\
20 & 4.77 & 4.18 \\
& & 3.54 \\
Mean & 3.53 & \\
\hline
\end{tabular}

* All values expressed in $\mu$ moles of ATP/g Hb. Assays were done by the enzymatic method.

\section{Reevaluation of the method of standardization of the luminescence technique}

In the firefly-luciferase technique described by Beutler and Baluda ${ }^{13}$, light resulting from the ATP of blood is standardized by comparison with light resulting 
from known amounts of ATP in aqueous standards. In preparing samples of blood for assay, inactivation of enzymes is achieved by boiling; there is no deproteinization and as a result, heme and denatured proteins are still present in the unknown samples. The presence of such compounds is a potential source for error in the method; they may absorb light or produce secondary fluorescence, which would not be compensated for in the aqueous standards. Since no wave length discrimination is employed in the measurement of emitted light, all luminescence, whether from the primary ATPluciferase reaction, or from secondary sources, is measured.

The possibility that denatured hemoglobin was contributing light to the system was evaluated by adding I $5 \mathrm{mg}$ of purified bovine hemoglobin (approximately the amount of hemoglobin contained in the o.I-ml blood sample employed in the luminescence method) to standards prior to boiling, and comparing the light emitted from these standards with that emitted from the usual standards. Results are shown in Table II (expts. I and 6). A marked increment in light output was observed in the

TABLE II

\begin{tabular}{|c|c|c|c|c|c|c|}
\hline \multirow[t]{2}{*}{$\begin{array}{l}\text { Experi- } \\
\text { ment }\end{array}$} & \multirow{2}{*}{$\begin{array}{l}\text { Amount of } \\
\text { standard* } \\
m l\end{array}$} & \multirow[t]{2}{*}{ Additions } & \multirow{2}{*}{$\begin{array}{l}\text { Number of } \\
\text { replicate } \\
\text { assays }\end{array}$} & \multicolumn{2}{|c|}{$\begin{array}{l}\text { Fluorometer } \\
\text { units*** }\end{array}$} & \multirow{2}{*}{$\begin{array}{l}\text { o Increment in lumi- } \\
\text { nescence produced by } \\
\text { additions }\end{array}$} \\
\hline & & & & mean & range & \\
\hline \multirow[t]{3}{*}{ I } & o.I & None & 10 & 34.6 & $27-4 I$ & \\
\hline & 0.1 & o.I ml A.W.B.** & 4 & 43.6 & $4^{2-45}$ & \\
\hline & 0.1 & I $5 \mathrm{mg}$ hemoglobin & 3 & $4^{2} .5$ & $3^{8-4^{8}}$ & 26.0 \\
\hline \multirow[t]{2}{*}{2} & 0.15 & None & 2 & 63.2 & & 22.8 \\
\hline & 0.15 & $0.1 \mathrm{ml} \mathrm{A.W.B.}$ & 2 & 71.5 & & 13.1 \\
\hline \multirow[t]{2}{*}{3} & 0.2 & None & 7 & 70.7 & $67-74$ & \\
\hline & 0.2 & o.I ml A.W.B. & Io & 82.6 & $79-86$ & I 6.8 \\
\hline \multirow[t]{2}{*}{4} & 0.1 & None & 4 & 37.9 & $35-42$ & \\
\hline & O.I & o.I ml A.W.B. & 4 & 45.0 & $44-46$ & $19 \cdot 4$ \\
\hline \multirow[t]{2}{*}{5} & 0.1 & None & 7 & 30.3 & $29-3 I$ & \\
\hline & 0.1 & o. I ml A.W.B. & 8 & 37.2 & $34-38$ & 22.8 \\
\hline \multirow[t]{6}{*}{6} & 0.05 & None & $\mathrm{I}$ & 5.0 & & \\
\hline & 0.05 & $15 \mathrm{mg}$ hemoglobin & I & 7.0 & & 40.0 \\
\hline & 0.1 & None & I & 9.5 & & \\
\hline & $0 . \mathrm{I}$ & $15 \mathrm{mg}$ hemoglobin & 2 & 14.5 & & 52.6 \\
\hline & 0.2 & None & I & 19.0 & & \\
\hline & 0.2 & I $5 \mathrm{mg}$ hemoglobin & 2 & $23 \cdot 7$ & & 25.0 \\
\hline
\end{tabular}

* Standard contained $0.4 \mathrm{mg}$ of ATP per $\mathrm{ml}$.

** A.W.B. stands for aged whole blood. Blood used for this purpose was at least 120 days old, and contained no measurable ATP as tested by the enzymatic method.

*** Fluorometer units refer to units of luminescence as measured by a Turner photofluorometer of the type specified by Beutler et l. $^{13}$. The absolute luminescence varies depending on the lot of firefly-luciferase being used.

standards to which hemoglobin had been added. Similar experiments were carried out in which o.I ml of aged whole blood (A.W.B.) with no measurable ATP remaining, were added to the standards (expts. I-5); once again an increment in luminescence was noted. The percent increment in luminescence appeared to be greatest in experiments where absolute luminescence was relatively low, and least in experiments where absolute luminescence was relatively high. In the range of luminescence usually encountered when using this method with fresh blood (20-50 fluorometer units), the increment averaged about $20 \%$. 
DISCUSSION

The reproducibility of the assay results after sample storage in the frozen state suggest that it will now be possible to conduct field studies of erythrocytic ATP levels in population groups remote from the investigator's base laboratory. Of several methods of preservation tried in preliminary studies this was the only method which gave excellent recovery of ATP. It seems to be necessary to precipitate the proteins prior to freezing. Simple storage of blood in the frozen state $\left(-20^{\circ}\right)$, with either addition of TCA prior to or subsequent to thawing, resulted in prohibitively large $(25-50 \%)$ losses of ATP. Extremely cold temperatures, either with or without precipitation of proteins, were not evaluated in these studies.

It is apparent that the presence of denatured hemoglobin in the cuvette leads to an increased output of light in the firefly-luciferase-ATP system. This may be due to secondary fluorescence induced in the system. The increment seems to average around $20 \%$, suggesting that the normal value for ATP reported by this method is falsely elevated by this amount in addition to about $5 \%$ overestimation due to other factors ${ }^{13}$. Even when correcting the data for a $25 \%$ overestimation error, the firefly luminescence method still gives a significantly higher (about $25 \%$ ) mean level of ATP in human erythrocytes than the enzymatic method. As Beutler et al..$^{13}$ have suggested, this may be due to some loss of ATP during the rather long extraction procedure involved in the enzymatic method. It would appear that when the "luminescence" method is used, either the standards should be assayed in the presence of hemoglobin, or an arbitrary $20 \%$ correction, based on the present data, should be employed.

Dept. of Medicine (Simpson Memorial Institute),

G. J. BREWER and Dept. of Human Genetics,

C. A. KNUTSEN University of Michigan Medical School, Ann Arbor, Mich. (U.S.A.)

G. J. Brewer, J. Lab. Clin. Med., (Abst.) 66 (Ig65) 858.

2 G. J. BREWER, Bicchem. Biophys. Res. Commun., I8 (1965) 430.

3 G. J. Brewer and R. D. Powell, Proc. Natl. Acad. Sci, U.S., 54 (I965) 74 I.

4 G. J. Brewer and R. D. Powell, J. Lab. Clin. Med., 67 (1966) 726.

5 G. J. Brewer, Ann. Internal. Med., (Abst.) 63 (1965) 912.

6 B. W. Gabrio, C. A. Finch And F. M. Huennekens, Blood, i i (i956) 103.

7 T. A. J. Prankard, Lancet, i (I956) 469.

8 M. Nakao, T. Nakao, N. Tatibana, H. Yoshikawa and T. Abe, Biochim. Bicphys. Acta, 32 (1959) 564 .

9 G. R. BARTLETt, Arch. Internal Med., I06 (1960) 889.

io A. W. Shafer and G. R. Bartlett, J. Clin. Invest., 40 (Ig61) i 178.

i I E. R. Simon, R. G. Chapman and C. A. Finch, J. Clin. Invest., 4 I (I962) 35 I.

I 2 E. Beutler and O. Duron, Transfusion, 5 (1965) 17.

i 3 E. Beutler and M. L. Baluda, Blogd, 23 (I964) 688.

I4 A. Kornberg, J. Biol. Chem., I82 (I950) 779 .

is B. L. Strehler and J. R. Totter, in D. GltCk (Ed.), Methods of Biochemical Analysis, Vol. I, Interscience, New York, I956, pp. 341-356.

Received May I7th, 1966 